\title{
Imaging microglial activation in tacrolimus-associated CNS vasculitis with translocator protein PET
}

Christoph Mahler, MD, Marcus Unterrainer, MD, Carolin Muth, MD, Rupert Egensperger, MD, Lena Vomacka, MSc, Simon Lindner, PhD, Birgit Ertl-Wagner, MD, Maximilian Patzig, MD,

Peter Bartenstein, MD, Nathalie Albert, MD, Martin Kerschensteiner, MD, and Tania Kümpfel, MD

Neurology ${ }^{\circledR}$ 2018;91:936-937. doi:10.1212/WNL.0000000000006516
Correspondence

Dr. Kümpfel

tania.kuempfel@

med.uni-muenchen.de

Figure $1 \mathrm{MRI}$ and PET

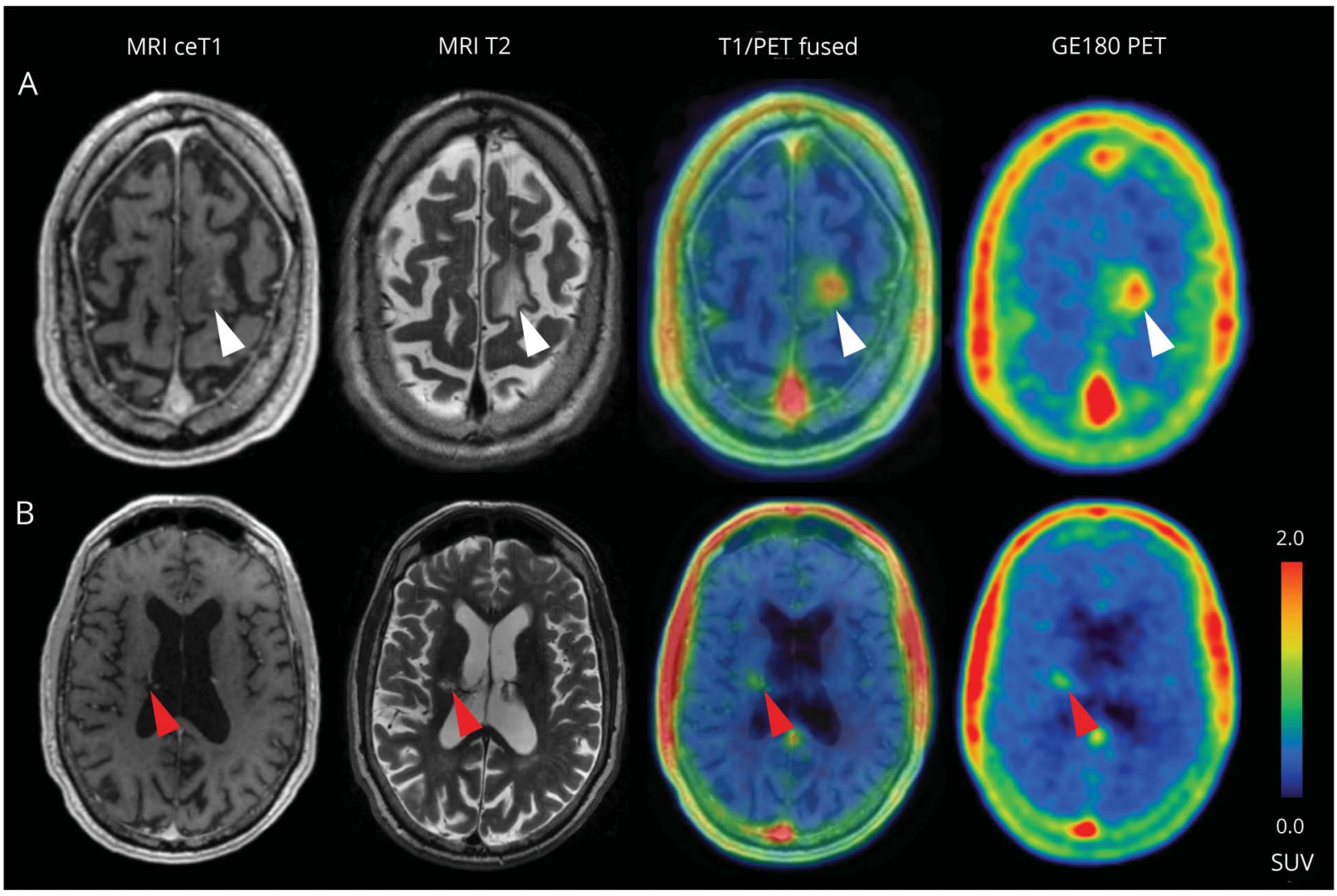

(A) MRI and $\left[^{18} \mathrm{~F}\right] \mathrm{GE}-180-T S P O-P E T$ reveal a contrast-enhancing lesion in the left gyrus frontalis superior. (B) Periventricular non-contrast-enhancing lesion with focal uptake in PET.

A 67-year-old man developed gradually worsening left-sided spastic hemiparesis under immunosuppressive therapy with tacrolimus after single lung transplantation. MRI revealed 2 diffusion-restricted, T2-hyperintense lesions without and with partial contrast enhancement, respectively (figure 1). Therefore, differential diagnosis mainly included progressive multifocal leukoencephalopathy, atypical CNS lymphoma, and CNS vasculitis. PET with the novel translocator protein (TSPO) tracer $\left[{ }^{18} \mathrm{~F}\right] \mathrm{GE}-180$ showed high focal tracer uptake in both

From the Institute of Clinical Neuroimmunology (C.M., M.K., T.K.) and Departments of Nuclear Medicine (M.U., L.V., S.L., P.B., N.A.), Neurology (C.M.), Radiology (B.E.-W.), and Neuroradiology (M.P.), University Hospital, and Biomedical Center (C.M., M.K., T.K.) and Center for Neuropathology and Prion Research (R.E.), LMU Munich; and Munich Cluster for Systems Neurology (SyNergy) (P.B., M.K.), Germany.

Go to Neurology.org/N for full disclosures. Funding information and disclosures deemed relevant by the authors, if any, are provided at the end of the article. 


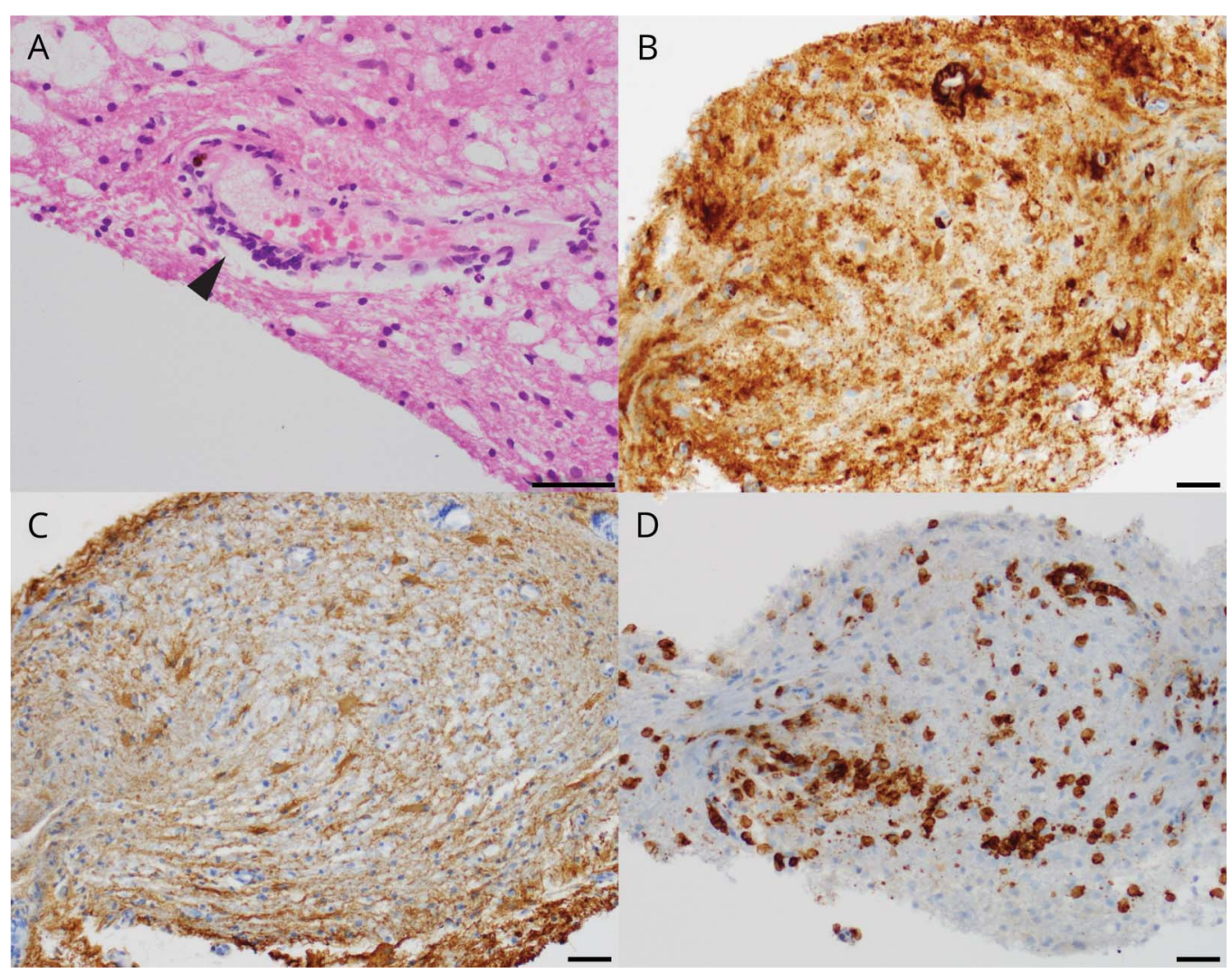

(A) Lymphocytic infiltration of small-vessel wall (arrow, hematoxylin \& eosin staining). (B) Microglial activation in CD3/43 staining. (C) Reactive astrocytes in glial fibrillary acid protein staining. (D) Infiltration of CD3+ T cells. Scale: $100 \mu \mathrm{m}$.

T2-hyperintense lesions. TSPO is overexpressed in activated micoglia. ${ }^{1}$ Stereotactic brain biopsy revealed tacrolimusassociated CNS vasculitis with distinct microglia activation, a rarely reported finding ${ }^{2}$ (figure 2). Our case thus suggests that TSPO PET might be a helpful tool for detection of active CNS inflammation ${ }^{3}$ in patients with suspected CNS vasculitis.

\section{Author contributions}

Christoph Mahler: study design, data collection, clinical care to the patient, drafting and revising the manuscript. Marcus Unterrainer: study design, acquisition and analysis of PET scans, critical comments during manuscript revision. Carolin Muth: clinical care to the patient. Rupert Egensperger: acquisition and analysis of histopathology images. Lena Vomacka: analysis of PET scans. Simon Lindner: acquisition and analysis of PET scans. Birgit Ertl-Wagner: acquisition and analysis of MRI scans. Maximilian Patzig: acquisition and analysis of MRI scans. Peter Bartenstein: study supervision and analysis of PET scans. Nathalie Albert: study supervision and analysis of PET scans. Martin Kerschensteiner: study supervision and critical comments during manuscript revision. Tania Kümpfel: study supervision and critical comments during manuscript revision.

\section{Study funding}

No targeted funding reported.

\section{Disclosure}

The authors report no disclosures relevant to the manuscript. Go to Neurology.org/N for full disclosures.

\section{References}

1. Dickens AM, Vainio S, Marjamaki P, et al. Detection of microglial activation in an acute model of neuroinflammation using PET and radiotracers 11C-(R)-PK11195 and 18F-GE-180. J Nucl Med 2014;55:466-472.

2. Pizzolato GP, Sztajzel R, Burkhardt K, Megret M, Borisch B. Cerebral vasculitis during FK 506 treatment in a liver transplant patient. Neurology 1998;50: 1154-1157.

3. Unterrainer M, Mahler C, Vomacka L, et al. TSPO PET with [F]GE-180 sensitively detects focal neuroinflammation in patients with relapsing-remitting multiple sclerosis. Eur J Nucl Med Mol Imaging 2018;45:1423-1431. 


\section{Neurology}

\section{Imaging microglial activation in tacrolimus-associated CNS vasculitis with translocator protein PET}

Christoph Mahler, Marcus Unterrainer, Carolin Muth, et al. Neurology 2018;91;936-937

DOI 10.1212/WNL.0000000000006516

This information is current as of November 12, 2018

$\begin{array}{ll}\begin{array}{l}\text { Updated Information \& } \\ \text { Services }\end{array} & \begin{array}{l}\text { including high resolution figures, can be found at: } \\ \text { http://n.neurology.org/content/91/20/936.full }\end{array} \\ \text { References } & \text { This article cites } 3 \text { articles, } 2 \text { of which you can access for free at: } \\ & \text { http://n.neurology.org/content/91/20/936.full\#ref-list-1 } \\ \text { Subspecialty Collections } & \text { This article, along with others on similar topics, appears in the } \\ & \text { following collection(s): } \\ & \text { MRI } \\ \text { http://n.neurology.org/cgi/collection/mri } & \text { PET } \\ & \text { http://n.neurology.org/cgi/collection/pet } \\ & \text { Vasculitis } \\ & \text { http://n.neurology.org/cgi/collection/vasculitis } \\ & \text { Information about reproducing this article in parts (figures,tables) or in } \\ & \text { its entirety can be found online at: } \\ & \text { http://www.neurology.org/about/about_the_journal\#permissions } \\ & \text { Information about ordering reprints can be found online: } \\ \text { Permissions \& Licensing } & \text { http://n.neurology.org/subscribers/advertise }\end{array}$

Neurology ${ }^{\circledR}$ is the official journal of the American Academy of Neurology. Published continuously since 1951, it is now a weekly with 48 issues per year. Copyright (O 2018 American Academy of Neurology. All rights reserved. Print ISSN: 0028-3878. Online ISSN: 1526-632X.

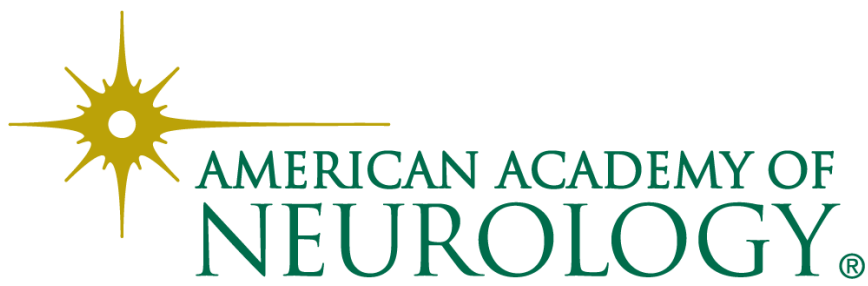

